\title{
El surgimiento de nuevas religiosidades en el contexto de la modernidad y de la postmodernidad.
}

\author{
The emergence of new religiosities in the context of modernity \\ and postmodernity.
}

Esta obra está bajo una Licencia Creative Commons Atribución 4.0 Internacional. DOI: https://doi.org/10.32870/sincronia.axxii.n74.31b18

\author{
Fabian Acosta Rico \\ Universidad de Valle de Atemajac \\ generalmiramon@yahoo.com.mx \\ (MÉXICO)
}

Recibido: $23 / 03 / 2018$

Revisado: $30 / 03 / 2018$

Aprobado: 22/06/2018

\section{RESUMEN}

En el presente trabajo es una reflexión acerca de las transformaciones que ha sufrido la praxis religiosa y la religiosidad en general a partir del proceso de secularización que comenzó con la reforma protestante. Todo inició con el desarraigo a una idea unitiva con lo divino propia de las religiones antiguas. En las religiones axiales, sobre todo las de matriz judeo-cristiana, Dios es un ser trascendente que le dio a la humanidad la oportunidad de elegir entre el bien y el mal; dicho Dios ya no está inmerso o indiferenciado en su creación, tampoco exige sacrificios o inmolaciones ni dispensa fortuna o suerte a cambio de veneración y culto.

Con el protestantismo devino una concepción de Dios llamada deísmo que esquematizó la relación entre el Creador y la creatura en la simplicidad de una frase: Él en el cielo, ocupado en sus asuntos; nosotros en la tierra haciendo lo propio. Luego devino una época de descreimiento militante y galopante. El ateísmo convertido en ideología se expandió por todo el mundo junto con las revoluciones socialistas; pero, como veremos en este artículo, a la luz de autores como Berger, Taylor, Corbí, Casanova, Armstrong... la religión sobrevivió al proceso de secularización y de modernización del mundo; y resurgió ya no en su carácter monolítico y dogmático de antaño, su renovación trajo consigo su pluralización. Ha surgido una nueva religiosidad derivada de la pluralidad, la des-dogmatización y mercantilización de lo sagrado; esta religiosidad es laxa y lúdica. De esto trata el presente trabajo. 
Palabras clave: Praxis religiosa. Mercado mundial de las religiones. Secularización. Postmodernidad. Laicismo. Dogma. Post-secularización. Religiones axiales. Desarraigo. Espiritualidad.

\begin{abstract}
In the present work it is a reflection on the transformations that the religious praxis and the religiosity in general have suffered from the process of secularization that began with the Protestant Reformation. All started with the uprooting of a unitive idea with the divine characteristic of ancient religions. In the axial religions, especially the matrix mathematics, God is a transcendent being who gave humanity the opportunity to choose between good and evil; said God is no longer immersed or undifferentiated in his creation, nor does he demand sacrifices or immolations, nor does he grant fortune or luck a change of veneration and worship.

With Protestantism became a conception of God called Deism that schematized the relationship between the Creator and the creature in the simplicity of a phrase: He in heaven, occupied in their affairs; we on earth doing the same. Then it became a time of militant and galloping disbelief. Atheism transformed into an ideology spread throughout the world along with socialist revolutions; but, as we will see in this article, in the light of authors like Berger, Taylor, Corbi, Casanova, Armstrong ... religion survived the process of secularization and modernization of the world; and it resurfaced no longer in its monolithic and dogmatic character of yesteryear, its renewal brought with it its pluralization. A new religiosity has arisen derived from plurality, the dedogmatization and commodification of the sacred; this religiosity is lax and playful. This is what this work is about.
\end{abstract}

Keywords: Religious praxis. World market of religions. Secularization. Postmodernity. Secularism. Dogma. Post-secularization. Axial religions. Uprooting. Spirituality.

Charles Taylor maneja la tesis del desarraigo como un proceso histórico y social que conllevó el abandono paulatino de las viejas formas y praxis de lo sagrado propias de la religiosidad antigua; en esencia, los cultos chamánicos y las religiones politeístas más avanzadas se sustentan en tres aspectos primordiales: un sentido de integración al cosmos; la idea acerca de que la naturaleza está inmersa en el ámbito de lo sagrado; y la confianza en que las divinidades dispensan todo tipo de bienes a cambio de la reciprocidad humana. (Taylor, 2006, p. 74) ${ }^{1}$

\footnotetext{
${ }^{1}$ Hay un retorno claro a este tipo de religiosidad donde la prosperidad es sacralizada; donde el ritual tiene la función de granjearse el favor del cielo para que este dispense su abundancia y prosperidad sobre el creyente: en ciertas Iglesias pentecostales la praxis religiosa suele estar centrada en rituales de la abundancia que le dan al milagro un carácter netamente mundano y utilitarista. El creyente acude a Dios, a través de la mediación de la Iglesia, no esperando el perdón de sus pecados, sino el remedio de sus necesidades.
} 
La obtención de los favores del cielo en la religiosidad antigua conllevaba la ejecución de un ritual que reclutaba el concurso tanto del hierofante como de la colectiva de creyentes; es decir, el sacerdote o brujo, junto con los convocados, realizaban las invocaciones o las plegarias a las divinidades para obtener sus favores y auxilios; o incluso eran invocados para apaciguar su cólera o desagraviarlos.

A diferencia de las religiones axiales o más contemporáneas; en las antiguas prevalecía un sentido integrativo con la naturaleza; entendida ésta como un todo; el ser humano era parte del cosmos aunque podía ocupar, según la concepción, un lugar de privilegio dentro de dicha totalidad; y su vez era parte de su propia comunidad: familia, horda, tribu, pueblo, ciudad... De su colectividad de origen recibía los elementos identitarios que le otorgaban un sentido y un fin existencial y social; sabía gracias a los mitos, a los relatos y muy posteriormente a los textos sagrados el significado de su vida, la finalidad de su existir y sobre todo el lugar y la función que debía cumplir dentro de las dos realidades antes mencionadas la macro cósmica (el mundo y la naturaleza) y la micro cósmica (su tribu o pueblo).

En la sociedades tradicionales prevalencia una jerarquía hierofánica o sagrada. La casta sacerdotal resguardaba los mitos y ejecutaba con pertinencia y rigor los ritos; estos hombres que servían de puente entre lo sagrado y lo profano se mantenían obedientes y diligentes a una comunidad de creyentes o fieles que aceptaban, como sus líderes y guía, a esta elite hierofánica.

El Cristianismo y de igual forma el Judaísmo, el Islam y el Budismo superaron las tres dimensiones de las religiones antiguas entendidas como orden social, armonía y comunión con el cosmos y bien humano; para estas religiones axiales la salvación o redención paso a ser un asunto entre la persona y lo divino; la naturaleza fue denigrada ontológicamente (engaño o ficción) o desacralizada existencialmente (lugar de tentación y pecado) y finalmente, y en consecuencia con lo anterior, la prioridad paso a ser la trascendencia y no la riqueza. (Taylor, 2006, p. 76)

El ser humano ya no entraba en contacto con los númenes en el bosque o en los estanques; lo divino, o como en el caso de las religiones teístas, Dios, el creador, trascendía sus obras; unirse a 
él exige un acto de renuncia y de auto-negación, es decir, demanda seguir ciertos lineamientos del ascetismo o, de menos, abrazar cierto grado de austeridad o pobreza. El verdadero creyente debe apegar su actuar y de preferencia también su pensar y sentir a un decálogo de renuncias y restricciones que le ayudarán a sortear las tentaciones o engaños mundanos y banales de una realidad insustancial. Logrado lo anterior, el puente desciende; el auxilio de la gracia o la propia iluminación despejan el camino a la realidad verdadera, auténtica, divina... Buscar la trascendencia dentro o fuera del mundo es entendida por Taylor como un desarraigo. ¿Desarraigo a qué? A la realidades macro y micro cósmicas.

Dicho desarraigo fue un primer paso a la secularización, o al moderno desvinculamiento entre lo social y lo sagrado. La privatización de lo sagrado implicó confinar el ritual y los símbolos hierofánicos o sagrados en los espacios templarios o su reclusión en el culto doméstico o personal.

Igual que Taylor, Peter Berger refiere que para muchas conciencias pre-modernas la solemnidad y el rigor ritual de las clases sacerdotales imponían un respeto enajenante sobre la muchedumbre de creyentes. El sacar a los sacerdotes de las plazas públicas y el privatizar el culto mediante la secularización (entendida en su sentido más anticlerical) marcó una liberación del individuo de la perniciosa y muchas veces tiránica influencia de la casta sacerdotal:

En círculos anticlericales y progresistas ha llegado a representar (la secularización) la liberación del hombre moderno de la tutela religiosa, mientras que en círculos vinculados con las iglesias tradicionales se lo ha atacado como sinónimo de descristianización, paganización. (Berger, 1977, p. 132)

Para Berger, el desarraigo y la consecuente secularización tuvieron lugar, primeramente, al interior de la fe judía. Las religiones de ella derivadas, Cristianismo e Islam, siguieron sus inercias históricas como lo fueron la trascendentalización de Dios, la historicidad de la revelación y la racionalidad de la ética. La naturaleza, a la luz de la fe judeo-cristiana, quedó despoblada de dioses paganos; el único Dios, el Dios de Israel, reside en los cielos, y tiene deparado un plan único de salvación para quienes cumplan sus mandamientos. 
Seguir o no el decálogo se volvió una elección. El ser humano podía decidir cómo ser libre dejando de ser una simple marioneta del destino o de los dioses; su liberación conllevó el aceptar el auxilio de Dios o, en contra punto, rechazarlo entregándose al mal y a la disipación. Es así que los seres humanos, confinados en el mundo, quedaban francos o libres para tomar el camino de la verdad y la justicia o seguir por la senda del error.

Dios, desde lo alto, vigila y evalúa nuestras acciones; permitiendo que los acontecimientos, hechuras del arbitrio humano, sigan, para bien o para mal, su curso. Desde su trascendencia, el Dios de Israel, y posteriormente el del Cristianismo e Islam, abría los márgenes necesarios, dentro del Cosmos, para dar cabida a la historia; a la historia unidireccional y ascendente; primero profética, luego darwiniana y finalmente progresista:

Puede decirse que la trascendentalización de Dios y el concomitante "desencantamiento del mundo" abrieron un "espacio" para la historia como escenario de las acciones divinas y humanas. Las primeras son ejecutadas por Dios, que permanece totalmente fuera del mundo. Las segundas suponen una considerable individualización en la concepción del hombre. Este aparece como el actor histórico ante el rostro de Dios... (Berger, 1977, p. 148)

Distanciar a Dios en la creencia de que está allá remoto o perdido en el Cielo profundo, hizo que su presencia dejara, en esta ausencia, de sentirse. Su auxilio ya no fue requerido en la medida que el ingenio humana buscaba las formas de procurarse el sustento, el bien y la felicidad. El ritual y los milagros perdieron relevancia. Ante los impredecibles socorros divinos, la ciencia y la tecnología ofrecieron soluciones a las necesidades humanas que no requerían de la fe ni de la devoción. Los santos y las legiones de ángeles intermediarios e intercesores podían quedarse recluidos en sus nichos en espera de devotos que desconocían o ignoraban los prodigios y descubrimientos del entendimiento humano.

Las leyes de Newton y el motor de combustión interna debían imponer la secularización, o derrumbe de todo puente entre el cielo y la tierra... los estratos económicos más cercanos al 
capitalismo y a la industria fueron los primeros en asimilar la secularización (Berger, 1977, p. 159). Sin embargo, un sector de la élite social y sobre todo las clases populares supieron mantenerse fieles a muchas de las viejas formas de la religión antigua (ritual, comunión con lo sagrado y comunitarismo religioso) manteniéndolas como elementos activos y sustanciales de una praxis religiosa popular.

La religiosidad popular es aquella que fluye del fervor religioso espontaneo del creyente; surge y corre al margen de la fiscalización de los guardianes de la ortodoxia religiosa; puede romper cánones y doctrinas establecidas por una racionalidad teológica que busca hacer comprensibles y manejables las experiencias y nociones de lo numinoso. ${ }^{2}$

En el caso de México, el Estado laico, salvo el episodio de la Guerra Cristera, siempre se ha mostrado tolerante e incluso indulgente con las manifestaciones religiosas públicas de carácter popular; y no podría proceder de otra manera, salvo que quisiera verse represor, autoritario y retrogrado; además, sus problemas y rivalidades, desde el siglo XIX y hasta comienzos del siglo XX, nunca fueron con el creer popular, sino con las elites eclesiásticas cuya influencia, riqueza y poder amenazaban la consolidación de un poder político libre de tutelas y de legitimaciones clericales.

En la actualidad, el Estado laico, incluido el mexicano, ya no está confrontado con la Iglesia ni es está una amenaza a su poder y más dado el clima de diversidad y pluralidad religiosa; su papel ya no es contener las injerencias clericales en asuntos políticos y económicos, sino servir de árbitro entre distintas confesiones que, como es de esperarse, tienden a rivalizar entre sí y competir clientelarmente por conservar creyentes o hacerse de nuevos conversos:

El Estado adopta ahora un rol frente a los grupos religiosos rivales que recuerda notablemente su rol en el capitalismo del laissezfaire: en esencia, el de un guardián imparcial del orden entre competidores independientes y no sujetos a coerción. (Berger, 1977, p. 161)

\footnotetext{
${ }^{2}$ Tomo el concepto de los numinoso como lo divino en su crudeza en su experiencia más tremenda e irracional.
} 
¿Cómo entender este escenario de pluralidad religiosa de frente a la consolidación del estado laico y ante el triunfo de la secularización? ¿No fue anticipado o erróneo el anuncio de Nietzsche acerca de la muerte de Dio? En realidad, si observamos bien las supuestas sociedades secularizadas; en ellas no pareciera estar Dios tan ausente; está presente; pero, de forma distinta o asumiendo representaciones cada más diversas. Reinterpretando la metáfora de Nietzsche, el "deceso" de Dios fue más bien un sacrificio; uno parecido al que sufrió el Hombre-Dios del teísmo cristiano: muere para luego renacer... Al interior de una modernidad post-secular, Dios resucita levantando, vaya la ironía, las ruinas y el polvo de viejos templos paganos; su regreso aluzó, también, el nacimiento de nuevas divinidades. El panteón de la postmodernidad es por demás ecléctico y plural caben en él los cultos más imposibles y los dioses más extraños (muchos de ellos creados o potencializados por el esoterismo de masas). El filósofo deicida (el Nietzsche profeta del Super-Hombre) al negar el cielo y sus consuelos queda obligado a afirmar esta otra realidad, más inmanente y tangible, llamada mundo; y lo hace con igual maestría poética, en su mito del eterno retorno. El mundo, tierra de conquista del Super-hombre, también resultó cargado de sus propios dioses; que despertaron con la estridente resurrección del antiguo Dios.

En palabras menos metafóricas, la muerte de Dios puede entenderse, a la manera de Freud, como una superación; la humanidad trasciende un estadio infantil cultural dominado por el pensamiento mítico, mágico y religioso y logra elevarse a uno en el que la ciencia esclarece todas las dudas y despeja ancestrales miedos.

En el deicidio o asesinato de Dios, cometido por esta modernidad antropocéntrica, algo de culpa cargan las propias iglesias y religiones. Refiriéndose a la fe católica, Mardones señala que la superficialidad teológica de la formación religiosa dispensada por la Iglesia contribuye al desencanto y al abandono del creyente; y advierte que los espíritus más audaces y deseosos de comprender buscan fuera lo que no encuentran dentro de su Iglesia. (Mardones, 1999, p. 27) ¿Y qué encontrarán afuera? Una galería abigarrada, confusa y contradictoria de viejos y nuevos dioses; de creencias arcaicas y de vanguardia. 
Como veremos más adelante, el creyente, a su placer o gusto, puede elegir el culto y la divinidad que le sea más a fines o llamativos ejerciendo su derecho de consumidor dentro del mercado mundial de las religiones. Por otro lado, los que no abandonan la iglesia en la que crecieron muy probablemente adolezcan de una fe débil y, por tanto, es común que ejerzan una praxis religiosa laxa que hace de los rituales y oraciones monótonas rutinas sin sentido o significado. En este tenor: "los sociólogos hablan del fin de la época de los practicantes, esto es lo que parece indicar el gran descenso de los que solicitan el tradicional servicio religioso...". (Wolny, 1998, p. 70)

Hay claras evidencias, como sostiene Mardones, de que un regreso a la praxis religiosa tradicional y a las viejas formas religiosas es muy improbable; la secularización ha logrado asentarse y desarraigarla requeriría de una coyuntura histórica trascendente y radical; puede que lo símbolos, roles y ritos recobren mucha de su antigua importancia; pero, difícilmente las sociedades modernas volverán a estructurarse entorna a la hegemonía de algún dogma religioso, como en antaño. (Mardones, 2004, p. 40)

María Corbí es aún más radical en su apreciación respecto a la venida a menos de la religiosidad tradicional; sostiene que, dado los nuevos contextos culturales, las generaciones presentes y venideras serán cada vez más reticentes a creer de forma dogmática pues tal acto implica fijar o anquilosar la elección. Guiados por sus gustos o preferencias ya no le apostarán a una sola idea o perspectiva; y más cuando tienen frente a ellos un mundo inmerso en el irrefrenable frenesí de cambios, transformaciones, novedades...

Un determinismo como el religioso que invita a dirigir la mirada al cielo esperando recibir de la providencia guía, consuelo, sentido y auxilio resulta incompatible, como dice Corbí, con un estilo de vida científico, industrial y dinámico al que, gradualmente, como humanidad, nos vamos habituando. (Corbí, 2007, p. 216) De lo anterior se puede deducir que las religiones tradicionales resultan, en lo esencial, anticuadas u obsoletas para los nuevos tiempos ya que dado su origen en una sociedad pre-industrial, agraria, autoritaria y patriarcal requieren ponerse al día o adecuarse a 
las nuevas dinámicas sociales y formas culturales de una postmodernidad comprometida con la pluralidad, la innovación y las des-dogmatización (Corbí, 2007, p. 214). Sin embargo, a pesar de su aparente obsolescencia, las religiones subsisten y algunas prosperan sorteando los retos de una modernidad cada vez menos identificada con los principios y banderas del ateísmo clásico.

Se puede decir que Modernidad y religión ya no son conceptos tan antitéticos como lo fueron en siglos anteriores. Es una exageración, a mi entender, sostener que la modernidad está forzando un descreimiento generalizado entre los individuos a la par que forja un tipo sociedad confiada en el progreso tecnológico y devota de la ciencia. El tren del progreso no arroyó a las catedrales antiguas; los viejos templos, mezquitas y sinagogas, salvo en Europa, siguen en pie y sus campanas o atalayas siguen llamando a los fieles a los oficios religiosos.

Para comprender mejor lo que ocurre en ésta difícil y compleja relación, entre religión y la modernidad, necesitamos partir de un enfoque menos maniqueo y más dialéctico observando cómo ambas lejos de rechazarse o repelerse guardan una mutua influencia e intercambio. No es exagerado afirmar que la modernidad ha adoptado muchas de las promesas e ideales de las religiones y que éstas, en particular las de matriz judío-cristiana, han inspirado y apuntalado muchos de los valores y principios de la modernidad como la: igual, libertad, respeto...

Como bien lo sostiene Mardones, no hay una sino dos modernidades o mejor dicho, tiene ésta dos rostro que se complementan pero que perfectamente pueden ser separados sin causarles mayores desfiguros. Por un lado, está la modernidad científico-técnica y económica y por el otro, la ilustrada, crítica y racional. La primera ha dejado de rivalizar con la religión; antes bien, no son pocos los cultos e iglesias que han sabido valerse de los adelantos tecnológicos para potencializar sus tareas de proselitismo y organización; en cambio, la segunda modernidad insiste, desde el siglo $\mathrm{XVIII}$, en mantener su desprecio por las praxis religiosas; sostiene sus cuestionamientos a las tradiciones y sigue rechazando todo tipo de verdad revelada. (Mardones, 1999, p. 30)

La modernidad, entendida como progreso material, ha replicado, desde su lógica mercantilista, algunas de las formas religioso. Como bien afirma Noah Harari las empresas son los 
nuevos templos que, en lo interno, mantienen un plantilla de nuevos hierofantes encargados de reclutar clientelarmente nuevos prosélitos que con orgullo digan Coca Cola es mi marca; o que presuman con toda jactancia el logo de su exclusiva marca de smartphone (Noah, 2016, p. 179). De igual manera ocurre con las celebridades artísticas o deportivas cuyo séquito de seguidores orbitan en torno a sus logros y vida personal (Noah, 2016, p. 181). Así como el culto religioso selecciona a los dignos de la gracia y los diferencia de los impuros e irredentos; así también el amparo de esta modernidad promete ser diligente o providencial con los ciudadanos de bien (civilizados y productivos) que aceptan y alimentan el orden establecido o sistema. Quien cumple con las reglas o algoritmos vera recompensada su docilidad y adaptación con seguridad; por ejemplo de enfermar sabemos que:

Mientras todos sigan las normas y los protocolos, existe una gran posibilidad de que nos curen. Según el ideal algorítmico, nuestra suerte está en manos del sistema y no en las de los mortales de carne y hueso que casualmente ocupan tal o cual puesto. (Noah, 2016, p. 183)

Sin embargo, pese a sus triunfos, el rostro progresista de la modernidad no ha podido sostener, como en sus comienzos, su casi monolítico y a veces satírico repudio a la religión. Esta modernidad, en lo ideológico, sembró la semilla de la secularización; al cosechar vio que el fruto obtenido era distinto al esperado o deseado; de su esfuerzo eclosionó una postmodernidad más que atea o agnóstica; plural y tolerante con todas las confesiones y creencias.

Resulta pertinente hacer el recorrido que nos llevó de la modernidad atea a la postmodernidad post-secular para formarnos una idea del futuro de la religiosidad y como éste parece no coincidir con el augurado por los hierofantes y profetas del cientifismo más logocéntrico: un mañana sin Dios y un mundo futuro libre de religiones.

El descreimiento u olvido de Dios, no sumieron de forma total la realidad en el caos del sin sinsentido, al menos no en los albores de la modernidad. Si el esfuerzo por racionalizar el misterio y lo trascendente, le permitió a las religiones tradicionales hacer compresible la realidad sagrada; con 
la instauración de una civilización tecnológica, regida por la economía, el misterio y lo sagrado dejaron de tener cabida en un mundo de fábricas y de transacciones comerciales.

El caos y el azar de esa junglada cultural dominada por las leyes del mercado, requería de un nuevo esfuerzo de racionalización y organización más utilitarista y por derivación secular o libre de toda normatividad religiosa. Como dice Berger: "A medida que se expande el complejo capitalistaindustrial, lo mismo sucede con los estratos sociales dominados por su espíritu, y es cada vez más difícil establecer sobre ellos controles tradicionales" (Berger, 1977, p. 163). Así como el misterio, tampoco el milagro resultaba relevante para una sociedad esperanzada en los frutos del intelecto humano.

No obstante olvidarse de Dios no resultaba del todo sencillo; había que dejarlo en el justo lugar, donde no perturbara la marcha del progreso o incluso la pudiera inspirar; como lo menciona C.S. Lewis, ese Dios trascendente, que desde su lejanía se limita a contemplar los logros y avatares de la civilización humana termino desdibujándose y diluyéndose en su creación. Para las mentes más modernas el mito de la encarnación de Dios en la persona de Jesús resultaba poco creíble a la luz de la razón que le arrancaba sus secretos a los átomos y a las galaxias; en cambio la idea de un Dios como un todo, al estilo de Spinoza (panteísta) resultaba más cómoda y creíble. Para Lewis, el panteísmo no es, en ningún sentido, una idea novedosa o moderna, sino todo lo contrario:

Panteísmo es la actitud en la que cae automáticamente la mente humana cuando se abandona a sí misma. Nada tiene de extraño que lo consideremos connatural. Si religión significa simplemente lo que hombre dice de Dios, y no lo que Dios es en el hombre, el Panteísmo es casi religión (Lewis, 2006, p. 132).

Armstrong por su parte considera que si hay una marcha franca hacía el ateísmo producto del olvido de Dios; más que al panteísmo, a su entender, la mentalidad moderna está inclinada hacía el deísmo, resultado del afán del cristianismo protestante de desvincular a Dios de la vida humana. Una máxima del deísmo es que Dios ya hizo suficiente con crearnos y establecer las leyes que gobiernan la naturaleza; nada más podemos esperar de Él. Si el Dios del teísmo requería de 
sacerdotes y rituales pues demandaba nuestra atención; esta divinidad deísta, este Dios de las mentes ilustradas del siglos XVIII, está tan alejada de la humanidad y del mundo que fácilmente se convierte en un Deus otiosus y termina por desaparecer de nuestra conciencia. (Armstrong, 2006, p. 490)

Perdido en lo inmanente o en lo trascendente; la modernidad ilustrada le apuesta al olvido de Dios; sin embargo, como hemos insistido, más que olvido, la idea de Dios resucita pero diversificada y mostrado múltiples máscaras, tantas como los anhelos y los deseos humanos.

La tardía modernidad renuncio a otorgarla significado o sentido al mundo pensándolo como la concreción de un plan divino; la renuncia pudo obedecer a la traumática experiencia con la sinrazón: guerras devastadoras, explotación irracional y depredadora de los recursos naturales... hicieron al ser humano dudar acerca de una observación y encauce providencial del cielo sobre los acontecimientos históricos. No obstante, un mundo sin un Creador no resultó mejor; por el contrario, había que sobrellevar la carga del absurdo; la razón, la ciencia y su progreso habían servido para darnos los instrumentos para aniquilarnos mejor; no podíamos culpar a nadie más que a nosotros mismos por nuestro empeño en explotar y destruir con demencia ecosistemas y naciones.

Ante la posibilidad de que el absurdo de la existencia y la sinrazón del mundo pudieran desquiciarnos; decidimos ocultarlos bajo un manto discursivo. Ante el imperio de una postmodernidad definida por la subjetividad y el relativismo, cualquiera podía darle sentido a las cosas mediante la palabra y la interpretación; eso sí, observando la regla de no apelar en esta tarea a ningún dogma o principio trascendente; bajo este entendido cualquier interpretación valía.

Así como Dios, la realidad quedaba también relegada. Sobre ella, la propia ciencia sólo podía darnos explicaciones parciales y aproximativas; jamás conclusivas. La realidad quedaba así remplazada por el texto; oculta bajo un membrete, o una interpretación construida a partir de las impresiones y valoraciones del observador e interprete. (Houtart, 2009, p. 59) 
Las religiones entraron también en este juego, como uno de tantos modelos explicativos sin mayores distinciones o prerrogativas que los demás discursos; la inclusión en el juego conllevaba la aceptación de sus reglas y contextos: diversidad, equidad y libre competencia. Como dice Wolny:

[...] el escaso interés por el futuro y el pasado, por el de dónde venimos y adónde vamos, que es sustituido por las secuencias flash... el individualismo light, el imperio de los débil, el pensamiento no-imperativo, el cuestionamiento de las supremas o grandes verdades y valores... La postmodernidad es tolerante o, mejor dicho, indiferente, suave, nodialéctica... (Wolny, 1998, p. 55)

En estos signos culturales evidenciados por la postmodernidad: la laxitud epistemológica, el relativismo moral y la des-dogmatización están cifradas las pautas de una nueva religiosidad que supera o que ha perdido, según se quiera ver, la rigidez racionalista de la vieja teología y de las religiones axiales (o teístas de tradición judío-cristiana) tal y como lo refieren Berger y Vattimo: el primero cuando habla de un escape postmoderno hacía la pluralidad religiosa y a la tolerancia; y el segundo al sostener la idea de una fe-débil y por tanto libre de verdades absolutas.

Las mentes postmodernas hacen extensivo su rechazo al racionalismo al propio logos de la ciencia y la tecnología que, como lo mencione atrás, este logos le falló a toda una generación que contempló, por igual, la vorágine de las armas de destrucción masiva así como la llegada del hombre a la luna. El desencanto de estos testigos encontró refugio en la irracionalidad; pero, entendiéndola no como negación tajante de su contraparte la racionalidad; la comprendieron más como un instrumento cultural de liberación del determinismo (racionalista y programático) de la vieja modernidad orwelliana encarnada en el estado totalitario, en particular en el comunista.

¿Es posible que está irracionalidad siente los cimientos también de esta nueva religiosidad en gestión? Podría ser, y más cuando contemplamos la tendencia en ciertas sociedades, como la estadounidense, en las que parece imperar la credulidad o adopción acrítica a cultos fundados en fantasías carentes de todo sustento simbólico sagrado o sin bases teológicas mínimas. El creer (como acto de la voluntad y de la razón) pierde su otrora sentido de seriedad y compromiso al verse 
cercado por una cultura de masas que pondera el espectáculo y que ya no pretende trasmitir ni formar, sino emocionar, sorprender y entretener. Está latente el riesgo de que la nueva religiosidad siga los derroteros de la cultura de masas.

El viraje de la religiosidad hacía la irracionalidad postmoderna tiene, para Mardones, la clara marca del desencanto y en cierta medida también la del pesimismo. En sus palabras, la marginación y la desigualdad económica y social padecida por la inmensa mayoría de la humanidad, la amenaza tecnológica con su promesa de ir remplazando al ser humana en todas las esferas tanto intelectuales como productivas, así como el relativismo cultura y la pluralidad propician un retorno a las formas y praxis religiosas arcaicas o incluso primitivas:

En esta situación crece la tentación de las posturas anti modernas y la vuelta hacia formas de pensamiento denominadas pre-racionales, ilógicas, que buscan por los caminos de lo sagrado salvaje, del esoterismo y de formas y experiencias religiosas plurales -no institucionalizadas- lo que la pretendida racionalidad económica o científico-técnica ni la religiosidad más tradicional no logran ofrecer. (Mardones, 1999, p. 13)

Mardones y Casanova sostienen, cada uno por su lado, que hay una destradicionalización y una pérdida de identidad resultado de este pluralismo y relativismo mezclado con la estandarización del gusto y el consumismo propios de la economía de marcado (Mardones, 1999, p. 11).

Por su parte, Casanova entiende que el desarraigo a las tradiciones religiosas y culturales conlleva un trasladarse y cobrar ciudadanía en una realidad global de fronteras identitarias y culturales indefinidas. En este contexto global, la identidad cultural, el sentido de pertenencia a determinado grupo o sociedad así como la fe religiosa pueden cambiar o mutar en el individuo sin miedos ni restricciones bajo la bandera de "mi vida, mis elecciones" (Casanova, 2004, p. 75).

La opción del descreimiento obvio que también está el menú de la postmodernidad; sin embargo más que ser "la opción" en contrapunto con las demás que sí implican una acción afirmativa respecto a la fe; es también ella una de tanta y una, por cierto, solo socorrida en occidente; o como dice Berger: 
[...] la teoría de la secularización que la gente abandone creencias y valores, sino más bien que estos ahora son elegidos más que sobreentendidos. Es decir, que el pluralismo no cambia necesariamente lo que la gente cree, sino cómo lo cree. (Berger, 2004, p. 66)

Retomando la idea del desarraigo y la pérdida de identidad, podemos decir junto con Berger, que la fidelidad y la pertenencia a determinada confesión son posturas propias de los viejos creyentes; para las nuevas generaciones sería más correcto hablar de preferencias religiosas (con todo lo veleidosas o indeterminadas que pudieran llegar a ser éstas). Obvio que una elección es reversible; y está determinada, en buena medida, por los gustos y las necesidades momentáneas. El sujeto de la religiosidad que intento definir, el postmoderno, el millennials, está anclado en el presente o, como dice Wolny, en lo inmediato, en el ahora y en las cosas que puedan satisfacerlo o saciarlo. Utilizando una metáfora por igual inteligente y poética, Wolny refiere que el símbolo fue siempre Prometeo, el titán que desobedeció, en provecho de la humanidad, a Zeus, trayéndole el fuego, símbolo del progreso; no obstante:

Los postmodernos desenmascaran a Prometeo y descubrieron que era Sísifo, un idealista fracasado. El símbolo de la postmodernidad ya no es Prometeo ni Sísifo, sino Narciso que, enamorado de sí mismo, carece de ojos para el mundo exterior... (Wolny, 1998, p. 54)

Narciso, prendido de amor hacía sí mismo tras contemplarse en el espejo de agua, es atrapado en el solipsismo de la autocomplacencia y autoafirmación; su mítica soledad recrea la del hoy popular cibernauta que se busca un "rostro" o una identidad en la web, desde la premisas de un autoconocimiento bastante superficial que reducen su yoidad a la esfera estética del parecer y mostrar y a la del gustar y disfrutar.

El remplazo del espejo de agua, entiéndase, el display del teléfono inteligente, de la computadora o de la smart tv, le dan al cibernauta escaparate; pero también le abren la puerta a una globalidad virtual traducida en millones de individuos interconectados; su dinámica de viajero del ciber-espacio le da un amplio y cosmopolita panorama; pero, físicamente lo enclaustra en un 
cuarto, lo ata a una silla y esclaviza su mirada a una pantalla... en esta paradójica condición de enclaustro y expansión, nuestro individuo se desenvuelve desde el plano de su individualidad a expensas o merced de sus impulsos, elecciones o momentáneas impresiones o gustos, sin reconocer más autoridad que su yoidad.

A propósito de nuestro tema de interés, la religiosidad, nuestro cibernauta también padece las consecuencias de esta modernidad tecnológica; como veremos con más detalle en las siguientes pinas, Internet le acerca a nuestro individuo mundos y realidades religiosas antes materia de enciclopedias y libros especializados; puede reproducir a la distancia, gracias al ciber-espacio, la vivencia de praxis y creencias distintas a la propia y puede darse la oportunidad de adoptarlas cual si fueran objetos culturales de consumo a disposición de cualquier interesado.

Esta libertad religiosa derivada en laxitud, en aras de un derecho, el derecho a elegir o decidir por uno mismo; en el fondo de ella subsiste una religiosidad individualista y personalizada, a la carta, o como dice Mardones la intención es:

Fabricarse una religiosidad a la medida de cada cual, que no tiene en cuenta la ambigüedad que recorre a toda manifestación de lo sagrado ni el lento aprendizaje de siglos de los mejores espíritus que lucharon en un lento y prolongado discernimiento por depurar la ganga de la mena en la religión. Esta ingenuidad ante lo religioso, vestida a menudo con los ropajes de la libertad y del no sometimiento a las iglesias establecidas, que se juzgan falsas y exclusivamente preocupadas por tradiciones y dogmas de factura meramente humana, tienen graves consecuencias: se cae en las garras del mercado y de la moda, de la influencia de un líder o de las reglas impuestas del momento. (Mardones, 1999, p. 29)

La postmodernidad exclamo no más dogmas ni metafísica. A su vez, con el mercado como instancia dominante (superando en influencia y poder al Estado) el nacionalismo y las ideologías políticas, que daban sustento doctrinal a los estados modernos, perdieron mucha de su antigua fuerza y trascendencia en los imaginarios sociales. Las religiones y las viejas iglesias resintieron de igual 
forma esta hegemonía de lo económico e igual que los partidos políticos, inmersos en la libre competencia electoral, las religiones y cultos tuvieron que darle a su discurso prosélito un formato mercantilista al verse obligadas a entrar al juego de la libre competencia entre iguales. Es entendible que muchos sacerdotes y pastores añoren la otrora hegemonía del cristianismo dentro de la civilización occidental; pero, como ya lo mencioné, el retorno al pasado es menos que imposible; los efectos sociales de la secularización son irreversibles.

Para que la Iglesia católica, la anglicana o la luterana volvieran a gozar de su pasada hegemonía moral y religiosa necesitarían antes recuperar mucho de su riqueza económica y sobre todo de su influencia política para así poder imponer las verdades y valores escriturados en sus dogmas. Lo anterior se antoja también imposible y más en tiempos donde los dogmas son cuestionados tanto en lo epistémico como en lo ético, con independencia de los poderes de facto que los abanderen.

Para la postmodernidad, bien lo dice Houtart, la verdad es sólo parcial; los criterios de verdad son democratizados o reducidos a la reservas y susceptibilidades del consenso y de la pluralidad: todas las opiniones, perspectivas, puntos de vistas y criterios son válidos; de tal suerte que no hay creencia o verdad religiosa descalificable en aras de la libertad y del derecho a elegir y experimentar cualquiera de las vías espirituales o religiosas ofertadas en el mercado mundial de las religiones. Proceder contra estos principios de libertad y tolerancia conllevaría riesgos, invocaría "demonios" del pasado como el fanatismo y la intransigencia; es decir, retrocederíamos a los tiempos en que los otrora dueños de la verdad encendían hogueras para quemar herejes, censuraban a los disidentes o los condenaban al destierro o la cárcel.

Así como los dogmas son repudiados y sentados en el banquillo de los acusados; de igual forma, las afirmaciones teológicas categóricas acerca de la existencia de un Dios único suenan chocantes pues en ellas sigue decantándose el viejo dogmatismo. Como dice Wolny, la nueva religiosidad, hija de la postmodernidad, prefiere representaciones de Dios exentas de la rigidez teológico-racional de la religiones axiales; encuentra más ad hoc y afines concepciones de lo divino 
más mistéricas como las que ofrecen las religiones orientales. Estos cultos exotistas (lo son para occidente obviamente) sostienen una idea de Dios inefable del que es necio afirma cualquier cosa; pues como tal trasciende o rebasa la finitud del entendimiento humano y por tanto más que comprenderlo lo conducente con Él es vivenciarlo... (Wolny, 1998, p. 64) Este Dios incognoscible resulta más próximo y verosímil a las nuevas teorías de la física que han transcendido el viejo modelo mecanicistas de mundo y enfilan más hacia concepciones y conceptos como relativismo y entropía.

Retomando lo antes dicho acerca de la resurrección de Dios, tras haber sido sepultado por la modernidad su renacimiento implicó su pluralización; pues reemerge no como uno, sino como una infinidad de viejos y nuevos dioses; en este sentido, podría decirse que el Dios mistérico de las religiones orientales es quien en realidad reemerge en esta postmodernidad reencontrándose y actualizando viejas concepciones acerca de lo divino como la del panteísmo y deísmo; ambas favorecidas por la ciencia y la filosofía modernas. En este punto hacen vértice modernidad y postmodernidad; el viejo dios del deísmo y panteísmo de los filósofos occidentales guarda similitudes formales, superficiales y forzadas con el dios de la New Age y de las religiones orientales (en esencia son el mismo); en ambas concepciones la idea de Dios puede ser relativizada y subjetivada tanto como lo decida o quiera el individuo: es decir, puede ser el dios Orisha, Changó (divinidad del fuego y los trueno) o, en su defecto, puede quedar definido en una idea acerca de lo divino tan abstracta y metafísica como la del Pléroma o Supra Ser del Gnosticismo. Dios es todo y al mismo tiempo es nada; gracias a su difuminación y des-dogmatización estamos en libertad y pleno derecho de buscarlo dentro y fuera de nuestra religión, cultura, pueblo y localidad.

Las nuevas tecnologías de la información favorecen dicha búsqueda y rompen el aislamiento de comunidades culturales cuyos símbolos, creencias, ideas y valores religiones pueden ahora circular fácilmente por todas las fronteras culturales las cuales, dicho sea de paso, han cobrado porosidad gracias a la des-dogmatización; misma que a su vez se ve acrecentada por esta libre circulación y pluralidad de creencias; como dice Berger: "El pluralismo tiene una consecuencia muy 
importante: mina el estatus de las creencias y valores que se dan por sentados, un proceso que afecta a la religión tanto como a cualquier otro componente de la cultura." (Berger, 2004, p. 66). En antaño, salvo religiones fundadas sobre hierofanías universales y por tanto proclives a la expansión más allá de su zona de nacimiento (Cristianismo, Islam y Budismo) el resto de los cultos, dada su identificación con un pueblo o cultura determinados, no tenían la pretensión de exportarse ni podían hacerlo en el entendido, por ejemplo, que para profesar y practicar el hinduismo era un requisito ineludible el haber nacido indio y de preferencia también en la India. Este carácter exclusivista de las religiosidades pretéritas aún persiste; sin embargo, ha menguado significativamente gracias a la globalización y al fenómeno de la translocalidad de las religiones; esta tendencia, como bien lo sostiene Casanova ha favorecido, principalmente, a las iglesias y religiones que desde sus orígenes han tenido una vocación o proclividad a la expansión:

Así, pues, la globalización de las religiones mundiales les ofrece no sólo la oportunidad de convertirse por primera vez en religiones verdaderamente mundiales -0 sea, religiones globales- sino también la amenaza de des-territorialización. Las oportunidades son mayores para aquellas religiones como el Cristianismo, el Islam y el Budismo, que siempre han tenido una estructura transnacional. (Casanova, 2004, p. 81)

A contra corriente de la globalización, muchas comunidades han consolidado y reactivado sus cultos y praxis religiosa; el retorno a los orígenes o a la raíz se entiende como una defensa de la identidad y del sentido comunitario que plantea toda una resistencia frente a las tendencias hegemónicas de un cultura y un esoterismo de masas que favorecen un tipo de religiosidad cada vez más individualista, lúdica y caprichosa. Tanto Casanova como Mardones previenen acerca del conflicto que puede surgir entre estas dos tendencias, la globalización y el localismo, entendiendo que la polarización hacia cualquier de las dos será negativa y problemática y urgen la necesidad de encontrar un sano e inteligente equilibrio entre la libertad y la identidad religiosas colectiva. (Mardones, 1999, p. 11) De tal suerte que los derechos comunitarios a los que apela un pueblo en defensa de su identidad religiosa; deben reconocerse bajo el compromiso de quienes los ejercen de 
no caer en la tentación del fundamentalismo o de los apasionamientos identitarios; de igual forma, la libertad de credo y de conciencia no deben propiciar una trivialización de la fe y de la lealtad religiosa. (Casanova, 2004, p. 83) Al parecer este sano equilibrio dejado a la voluntad individual y colectiva de los practicantes o creyentes es difícil de alcanzar; en defensa de viejas preferencias, localista e individualistas, optan por descalificar al contrario y a acreditar su postura como la correcta enfatizando la exclusión de otras, de las diferentes o discordantes. El radicalismo, en este caso, dará virajes hacía una polarización que bien saldrá, en uno de sus extremos, en defensa de la pluralidad o podrá decantarse, con dirección contraria, por el fanatismo. En ambos casos, la religiosidad termina desvirtuándose siendo blanco de críticas. En el juego de los extremismos e intransigencias; unos defenderán la pluralidad otros preferirán permanecer, a buen resguardo, en el fortín del dogmatismo. Cualquiera de estas posturas, le termina dando la razón a los seguidores de un ateísmo militante y proselitista siempre resuelto a denunciar la irracionalidad o las actitudes fanáticas de las religiones.

Valdría decir, ya para concluir, que este tipo de señalamientos y críticas son cada vez menos ponderadas o tomadas en cuenta por la colectividad de creyentes; el poco eco que tiene el denunciar las supuestas incoherencias o inconsistencia de algún dogma religiosa se debe, en buena medida, a la postsecularización que impuso, casi como norma o regla, el respeto a las creencias ajenas y el derecho a discrepar incluso de las verdades más científicas.

\section{Referencias:}

Armstrong, K. (2006). Una historia de Dios 4000 años de búsqueda en el judaísmo, el cristianismo y el islam. España: Paidós.

Berger, P. (1977). El Dosel sagrado. Para una teoría sociológica de la religión. Argentina: Amorrortu editores.

Berger, P. (2004). Globalización y religión. Iglesia viva: revista de pensamiento cristiano. 
Casanova, J. (2004). Religiones públicas en un mundo global. Iglesia viva: revista de pensamiento cristiano.

Corbí, M. (2007). Hacía una espiritualidad laica. Sin crrencias, sin religiones, sin dioses. España: herder.

Houtart, F. (2009). Mercado y religión. Panama: Ruth Casa Editorial.

Lewis, C. S. (2006). Los milagros. Estados Unidos: HarperCollins.

Mardones, J. (1999). Nueva Espiritualidad. Sociedad moderna y cristianismo. México: Iteso.

Mardones, J. M. (2004). ¿Hacía donde va la religión? México: Universidad Iberoamericana.

Noah Harari, Y. (2016). Homo Deus. México: Debate.

Taylor, C. (2006). Imaginarios sociales modernos. España: Paidós.

Wolny, W. (1998). El mundo postmoderno y la religiosidad. Escuela abierta. 